Article

\title{
Sustainability through Non-Agricultural Business Development in Resident Cooperative Planning: A Case of Korea's Rural Area
}

\author{
Seon Gyeong Baek ${ }^{1, *(D)}$ and Hyun-Ah Kwon ${ }^{2, *}$ \\ 1 The Institue of Asian Culture, Mokpo National University, Jeollanam-do 58554, Korea \\ 2 Department of Architecture, Mokpo National University, Jeollanam-do 58554, Korea \\ * Correspondence: mediatespace@naver.com (S.G.B.); helenack@naver.com (H.-A.K.); \\ Tel.: +82-10-9899-4000 (S.G.B.); +82-61-450-2729 (H.-A.K.)
}

Citation: Baek, S.G.; Kwon, H.-A.

Sustainability through

Non-Agricultural Business

Development in Resident

Cooperative Planning: A Case of

Korea's Rural Area. Sustainability

2021, 13, 1323. https://doi.org/

$10.3390 /$ su13031323

Academic Editor: Karina Pallagst

Received: 28 December 2020

Accepted: 24 January 2021

Published: 27 January 2021

Publisher's Note: MDPI stays neutral with regard to jurisdictional claims in published maps and institutional affiliations.

Abstract: This study analyzes a participatory regeneration project implemented for sustainable improvement as the center of Yeongju, a rural area in Korea, declines. The paper explains how participants were chosen from the mostly elderly population and encouraged to participate. In this case, a small, non-agricultural business that existing residents could maintain was conceived and implemented with a focus on cooperation rather than agricultural recovery or urbanization through the construction of large apartments and new industrial complexes. To this end, the administration continues to support the community from a long-term perspective, and experts have consistently made practical implementations among them. The participating community is not fixed but flexibly reorganized based on the progress of the project. In addition, by creating public community facilities, residents can continue their activities. This study emphasizes that participatory planning does not necessarily imply a retreat to the administration and experts and provides important guidance for implementation under similar conditions in the future.

Keywords: resident cooperative planning; participatory regeneration planning; non-agricultural business development; community organization; elderly participation; rural area decline; public community facility; community operation

\section{Introduction \\ 1.1. Rural Area Decline and Improvement through Regeneration}

Since the twentieth century, many regions around the world have become urbanized. Metropolitan cities in East Asia, including China, Korea, and Japan, have the highest population density in the world [1], and the concentration in cities is accelerating. In large cities with location advantages, the results of enormous developments manifest alongside the emergence of political power. Meanwhile, in rural areas that are not affected by transportation, industry, tourism, and so on, the decline is rapid as the population decreases and ages.

In the case of Korea, during 35 years of Japanese colonial rule, land was collectively organized according to the Urban Planning Act of Japan, and urbanization began in earnest in the 1960s after liberation in 1945 [2]. In particular, metropolitanization has rapidly progressed in areas such as Seoul, the capital city, and Daejeon and Busan, which are major transportation hubs. Today, the urbanization rate in Korea is $81.4 \%$ [3], and the gap between urban and rural areas is increasing. The Organization for Economic Cooperation and Development (OECD) has already highlighted this gap in Korea and mentioned the lack of policy to prepare for a decline due to aging [4]. Accordingly, the Korean government has set the following indicators to assess and manage such a situation: the decline is diagnosed through a decrease in the number of people and businesses and the deterioration of the living environment. The number of people and businesses decreases 
by $20 \%$ and $5 \%$, respectively, for three years in a row; if more than $50 \%$ of old buildings are over 20 years old, the area is considered deteriorated [5].

Recently, international improvement directions and practices have been discussed in terms of the development of idle land or old buildings in rural areas [6,7]. In Europe, while monitoring these changes, a multidimensional approach has been attempted in terms of not only physical issues but also social, economic, and psychological issues [8]. Particularly, the existing agriculture-based sales and production strategies have been dealt with, and tourism development has been a major method for regional activation [9-11]. However, when population decline and aging occur in small and medium-sized rural areas, it may be difficult to overcome this decline through agriculture or rural tourism based on residents. In such a situation, to make an improvement, one of the essential goals is to ensure that the inflow rate is higher, or kept stable, compared to the outgoing population. However, for this purpose, growing the local economy by attracting new industrial complexes in areas where there is no geographical advantage, or attracting the population of surrounding areas through large-scale residential development, may not necessarily be an effective strategy.

The Korean government promotes the improvement of the physical environment and economy in general through public projects in small and medium-sized rural areas, which have a high proportion of elderly residents and are difficult to revitalize through close relationships with other regions. Above all, sustainable revitalization of rural areas is implemented through "regeneration" rather than full redevelopment [12]. Unlike in Europe and the United States, where discussions on regeneration had already started in the 1960s, the Special Act on Revitalization and Support for Urban Regeneration (SAUR) was announced in 2013. Since then, procedures and methods have been devised through several pilot projects.

The target sites for regeneration in Korea today are largely selected in relation to two aspects: relatively underdeveloped places in metropolitan areas and a declining center in rural areas. In the regeneration of this rural area in Korea, the administration is comprehensively involved over a long period of time in the overall improvement of the physical environment, beyond only aspects such as the recovery of agriculture or land development. Accordingly, it secures the stability of residences and strengthens the economic power to ultimately lead to a sustainable life.

\subsection{Sustainability through Community Participation and Non-Agricultural Business Development}

In Yeongju, a rural area, a regeneration project to improve the central decline was implemented, showing the possibility of sustainable urbanization. When it comes to public policy, sustainability is a concept that most governments recognize as a major political goal in a wide range of fields, and since its definition is general and neutral, there are quite a variety of strategies [13]. The main issues in the regeneration project implemented in Yeongju in Korea regarding the ultimate goal of sustainability are as follows:

The administration has attempted to make decisions by discussing with the local community - which is the real base of the region and the subject of future sustainabilityrather than completely leading the planning for development. However, recent community participation projects in Korea have been constantly criticized: as the government controls the process after project implementation and support, community-centered sustainability becomes impossible [14].

Unlike the United States and Europe, in Korea, community participation began to be discussed in public projects in urban and architectural fields in the 1990s, and participatory public projects were conceived in earnest following the announcement of the SAUR in 2013 [15]. However, it is necessary to recognize that, in many cases, the administration still needs to seek, form, and encourage communities to participate. Of the participatory public projects so far, around $70 \%$ have been implemented under these conditions, excluding temporary participation by unspecified residents [16]. Therefore, administration and experts should consider a cooperative and consultative method by understanding the conditions 
occurring in the transition period to the deliberation system rather than expecting the immediate, voluntary participation of the residents.

Moreover, administration and experts recognized that it is impossible to revitalize the economy and environment through existing agriculture due to the aging population. Accordingly, through discussions, they developed a non-agricultural business that would gradually adapt to the urban system and act as an amplifying agent for regional activation.

This study identifies the solutions that the administration and experts have found and implemented by consulting with residents on sustainability through case analysis, and it discusses the key characteristics and major roles of each subject.

\section{Materials and Methods}

Yeongju is a small city in Korea that is not adjacent to large cities such as Seoul and Busan (Figure 1). The main source of income is apple farming and fabric production. The population of Yeongju is around 100,000; since the 2000s, it has rapidly decreased, giving way to the aging phenomenon [17], which has prominently occurred in the center of the region. Economic production activities have declined in relation to these demographic characteristics.

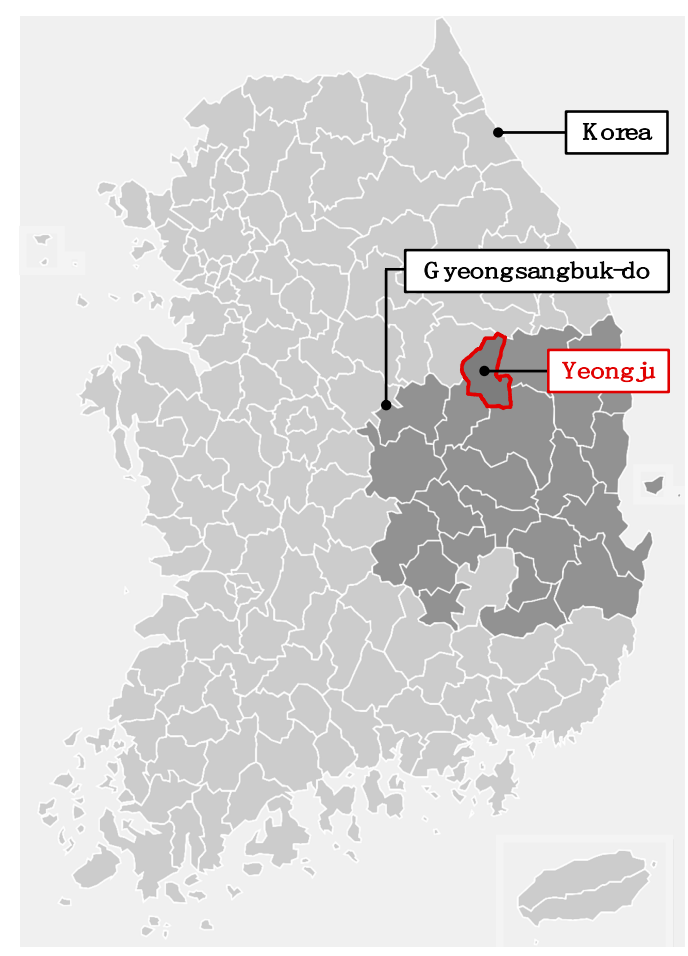

Figure 1. Map of location of Yeongju in Korea (Source: Wikipedia; reproduced by authors).

This central decline is currently faced by many rural areas in Korea. In the early twentieth century, Korea was a Japanese colony (1910-1945). At that time, Japan set Korea as a food base, and accordingly, railroad facilities were installed in each agricultural area for the export of rice and grain. During the colonial period, the area around railway stations in the region was a place where agriculture was revitalized, and markets for the exchange of goods flourished [18]. Meanwhile, from the 1960s, Korea pursued radical development by rebuilding new stations and related facilities in each city; accordingly, the areas around previous stations gradually declined. The center of Yeongju was one of the places where this phenomenon occurred as the station moved to another location in 1973 (Figure 2). 


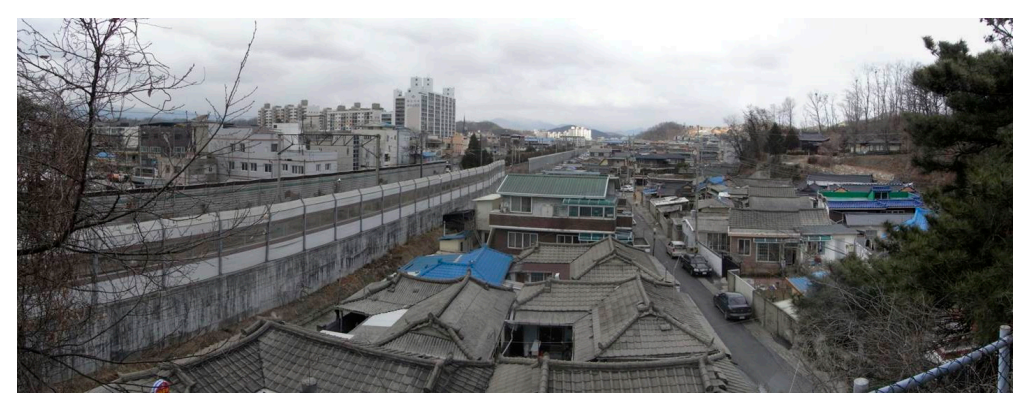

(a)

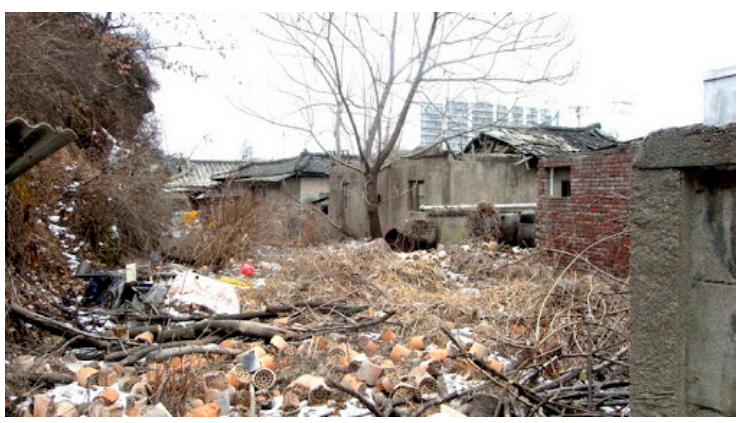

(b)

Figure 2. Declining center of Yeongju: (a) Panoramic view; (b) Residence with street (Source: YCG).

The Yeongju City Government (YCG) recognized the decline and problems and began to seek activation plans in 2008. In particular, an integrated diagnosis and master plan work for Yeongju was attempted through the "National Land Environment Architecture Design Demonstration Project" promoted by the Ministry of Land, Infrastructure and Transport (MOLIT) [19]. The YCG had an internal execution organization, and in collaboration with the National Policy Research Institute and the Architecture and Urban Research Institute, it promoted extensive research and planning for the region. From a long-term perspective, the following points were made:

First, in the case of this area, unlike other areas in Korea that had been significantly improved through full redevelopment projects, it was evaluated that the location and economic conditions were insufficient for the same improvement to occur. Accordingly, the YCG set a direction based on existing physical and non-physical conditions rather than a completely new method by considering sustainability. In particular, considering the aging of the population, determining the suitability of rehabilitation and promoting existing agriculture was an important task to be addressed.

In addition, it considered the possibility of local revitalization by improving and creating public architecture and public spaces, which are part of the actual living environment of residents. The YCG attempted to undertake related projects, judging that the local environment and life could be linked and integrated by improving public places [20] (pp. 20-22). In 2011, the practical possibility and significance of community participation in the planning and operation of public facilities was confirmed through pilot projects of the MOLIT and the Ministry of the Interior and Safety (MOIS) [21] (p. 23).

Then, in accordance with the central government's announcement of the Special Act on Urban Regeneration in 2013, regeneration projects started nationwide, and in this regard, the central area of Yeongju was selected as a leading project site. Accordingly, the first year of implementation was 2014, with a budget of approximately USD 31 million, which included funds from local governments and private investments.

Table 1 shows an overview of the process of this long-term implementation to overcome the decline in Yeongju and revitalize the city.

The scope of the regeneration project encompassed $1.51 \mathrm{~km}^{2}$ in total; it was divided into three regions according to the characteristics of each and was carried out over four years. The first two areas subject to improvement were markets: the project aimed to revitalize their surroundings by creating a space for culture and arts, preserving and using modern buildings that were 40-50 years old. Among the three districts, Guseong Village, with a population of 113,417 occupying 74,259 $\mathrm{m}^{2}$, was the key site for improvement [22] (pp. 16-17) (Figure 3). At that time, 71\% of Guseong Village included old buildings that were over 30 years old. In addition, the proportion of the severely aging population aged 65 and over was 73.9\%, with 35\% being non-income earners and $29.29 \%$ being basic living recipients who had financial problems. This study identifies the development contents and implementation process of non-agricultural projects promoted through consultation with residents for the improvement and sustainability of Guseong Village. 
Table 1. Process of improvement and activation of decline in Yeongju.

\begin{tabular}{|c|c|c|c|c|}
\hline Process & Scope & Period & Main Purpose and Contents & $\begin{array}{l}\text { Financial Support and } \\
\text { Decision Maker }\end{array}$ \\
\hline Master Plan Project & Yeongju & $\begin{array}{l}\text { Around two } \\
\text { years }\end{array}$ & $\begin{array}{l}\text {-Identify the decline and seek } \\
\text { directions for improvement } \\
\text {-Public architecture and public } \\
\text { space integrated system } \\
\text { construction }\end{array}$ & $\begin{array}{l}\text {-Central department: MOLIT } \\
\text {-Local government: } \text { YCG }^{2}\end{array}$ \\
\hline $\begin{array}{l}\text { Residential } \\
\text { environment } \\
\text { improvement } \\
\text { project }\end{array}$ & $\begin{array}{l}\text { Yeongju: three } \\
\text { declines area }\end{array}$ & $\begin{array}{l}\text { Around two } \\
\text { years }\end{array}$ & $\begin{array}{l}\text {-Improvement of residential area } \\
\text { and historical and cultural } \\
\text { environment } \\
\text {-Public building improvement and } \\
\text { creation: seeking community and } \\
\text { inducing participation }\end{array}$ & $\begin{array}{l}\text {-Central department: MOLIT }{ }^{1} \text {, } \\
\text { MOIS }{ }^{3} \\
\text {-Local government: } \\
\text { Gyeongsangbuk-do }{ }^{4}, \text { YCG }^{2}\end{array}$ \\
\hline $\begin{array}{l}\text { Preparation for } \\
\text { regeneration project }\end{array}$ & Yeongju central & $\begin{array}{l}\text { Around one } \\
\text { year }\end{array}$ & $\begin{array}{l}\text {-Investigation and confirmation of } \\
\text { range and characteristics of the } \\
\text { decline in the center, finding } \\
\text { various ways }\end{array}$ & -Local government: YCG ${ }^{2}$ \\
\hline $\begin{array}{l}\text { Planning and } \\
\text { execution of } \\
\text { regeneration project }\end{array}$ & $\begin{array}{l}\text { Yeongju central: } \\
\text { Guseong Village } \\
\text { and around the } \\
\text { two markets }\end{array}$ & $\begin{array}{l}\text { Around four } \\
\text { years }\end{array}$ & $\begin{array}{l}\text {-Specify and execute plans for } \\
\text { improvement of decline through } \\
\text { community participation } \\
\text {-Establishment of centers and } \\
\text { organizations for continuous } \\
\text { implementation of regional } \\
\text { regeneration } \\
\text {-Establishment of public resident } \\
\text { facilities, operations, and } \\
\text { management by residents }\end{array}$ & $\begin{array}{l}\text {-Central department: MOLIT }{ }^{1} \\
\text {-Local government: } \\
\text { Gyeongsangbuk-do }{ }^{4}, \mathrm{YCG}^{2}\end{array}$ \\
\hline
\end{tabular}

${ }^{1}$ Ministry of Land, Infrastructure and Transport; ${ }^{2}$ Yeongju City Government; ${ }^{3}$ Ministry of the Interior and Safety; ${ }^{4}$ Province to which Yeongju belongs.

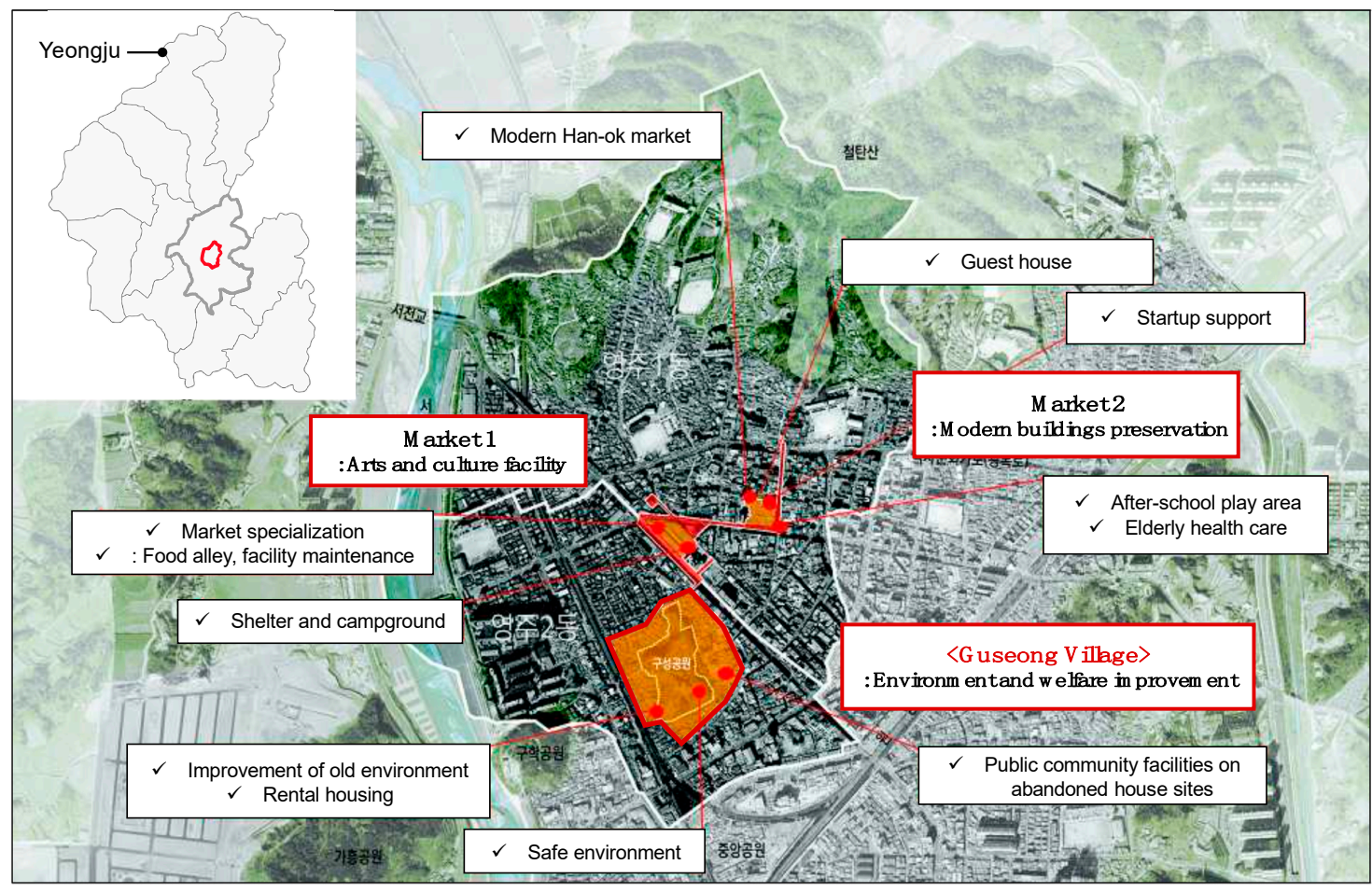

Figure 3. Regeneration plan in the center of Yeongju (Source: YCG; reproduced by authors). 
This study analyzes local improvement plans through resident participation-based regeneration projects. As mentioned in Section 1 above, since participatory public plans in Korea were implemented in earnest in the 2000s, systematic discussions on these projects for future action have not yet been made. In particular, there have been positive discussions after the regeneration project for the center in Yeongju, as sustainable results were revealed. The case of Guseong Village in Yeongju has been discussed in domestic journals, reports, and media $[19,20,22,23]$. However, these existing discussions have focused mainly on the promotion of the administration and improved results rather than analyzing the residents' participation process and issues as important.

Although the authors of this article were not directly involved in the execution of the business in Yeongju at the time, through detailed investigation and analysis of the case, this study lays the foundation for research on the current situation in Korea and draws out the main characteristics of the process for implementation under similar conditions in the future. To this end, the records of official meetings of the three actors-administration, expert, and community-and data scattered about the implementation process were primarily researched and systematically organized. In addition, detailed analysis was conducted through e-mail and telephone correspondence with stakeholders, and through online and offline surveys at the actual site.

As this study considers that the cooperative decision-making process has led to the main results, the process and results are identified in Section 3, and the main characteristics and significance are discussed in Section 4.

\section{Results}

The Korean government has implemented a regeneration project, noting the rapid decline in the centers of rural areas and underdeveloped areas in large cities. As mentioned earlier, as in most cases in Korea, the basic idea of improvement in Yeongju was initiated by the administration. They were aware of the problem and set their directions with experts. In addition to improving the environment, practical livability through economic independence is an important task for Yeongju. In particular, considering the aging population of the region, agricultural recovery could be expected, and the creation of new industries and residential areas was likely to dismantle or destroy assets, including existing communities. For this reason, to ensure sustainability, from the initial planning stage, through consultations with residents, a feasible plan was sought. After reaching a concrete plan, public community facilities were constructed by utilizing idle lands, and economic power was created based on these facilities, leading to a sustainable way of life in the region. The analysis and results of the administration's public project promotion and participatory planning are described in the following three subsections.

\subsection{Public Project Promotion by Administration before Planning}

Local residents have made no voluntary move regarding the decline in the center of Yeongju, and the administration has begun to improve and revitalize it based on the awareness of the problem. As mentioned in Section 2, YCG initially prepared and envisioned a regional master plan for around two years as the first step toward improving the situation. Two years later, in 2013, the central government prepared a law (Special Act for Urban Regeneration) to improve declining areas across the country, and support for regions was promoted; YCG prepared an application for this.

The central government set the primary goal of intensive recovery and improvement in areas with severe decline, while at the same time making specific demands. First, the project was developed as a regeneration project that maintained the characteristics of the existing people and places. In addition, as in many existing public projects in Korea, it would not be conducted top-down with the government leading a large-scale development; rather, the residents would participate in the overall process, so that practical problems in the region could be solved. 
Accordingly, the YCG first clarified the area of improvement in the center through a survey of its basic status. In the process, the focus was on the serious decline of Guseong Village, seeking solutions for the regeneration of the region through the activation of nearby markets. However, this administration did not directly suggest sustainable solutions. In particular, in Guseong Village at that time, elderly people who could no longer continue agricultural or industrial activities were living in very poor environments, and as abandoned houses increased and garbage accumulated on the streets, even in the center of Yeongju, the area was becoming increasingly deteriorated. The YCG was aware of this situation and, accordingly, first set the goal of improving the environment rather than making a hopeful plan for the participation of residents. Then, the administration decided to find specific solutions in the future by collecting and discussing opinions from various stakeholders, including residents. In addition, the possibility of revitalizing the area centered on public places by utilizing the abandoned estate in Guseong Village, which was recommended according to the master plan of Yeongju.

The YCG began consulting with experts in this regard. The administration prepared for the implementation of a participatory public plan by sharing and consulting with experts on the general goals and schedule of the regeneration project. In particular, in the case of experts, a professor in the department of architecture from a nearby university was appointed as the general manager, and an architect, a practical activity expert in this area, joined as a coordinator.

\subsection{Community Participation and Decisions in the Planning Process}

After joining the experts, it was the scrutiny of the site that took up most of the initial period. They specifically confirmed the contents and statistics previously investigated by the administration through a detailed survey of the actual site. In particular, although the project was going to be promoted as a participatory plan, it did not reveal which residents could participate; thus, the search for the residents was conducted in concomitance with the implementation of the project.

The types of communities and content of participation formed in the search process are as follows. Initially, the Guseong Village Council was formed-a kind of preliminary council for the purpose of building an initial community by examining existing community groups and identifying active residents. Then, the administration and experts held resident meetings, conducted individual interviews and questionnaire surveys, and drew up the direction of the plan by supplementing the survey on the region. In addition, a resident presentation was held to formally share information on the project plan with the local residents and gather comprehensive opinions. Guseong Village showed a seriously underdeveloped environment that required the immediate removal of garbage. For this reason, the residents first demanded that the administration solve environmental problems in housing and streets. Furthermore, the administration and experts consulted with the residents to create an independent profit structure, so that the solution through public intervention could lead to a sustainable life for the residents. In particular, it was envisioned that such a plan could be prepared focused on the creation of public resident facilities.

During the year of preparation of this general plan for the central government's financial support for the regeneration project, site surveys were conducted 24 times, and residents' meetings were conducted 27 times. In addition, 43 residents were interviewed, and a questionnaire survey was conducted with 74 people. Education programs such as lectures and field trips were held for a total of 19 times to strengthen residents' capacity for sustainable participation [21] (p. 25).

Particularly, administration and experts did not consider participating community groups as fixed. After the project was confirmed, a workshop was held to initiate the implementation of the regeneration plan, and the existing Guseong Village Council was reorganized into the Guseong Village Urban Regeneration Project Steering Committee (Resident Promotion Committee). In addition, resident leaders and "activists" were elected to establish a framework of cooperation with the residents; these were not necessarily 
professionals but rather village residents who best knew the region and showed positive attitudes toward improvement. "Activists" were also included in the organization of the Project Promotion Council by region.

However, the formation of a community organization in this way did not mean that the administration and experts could immediately implement the full-scale plan by relying on the residents. Since most of them were elderly, it was not an easy task to obtain consent for sustainability and encourage participation, which made it difficult to find solutions together [24]. In addition, many development projects in conditions similar to those of Guseong Village have mainly focused on building apartments through full redevelopment, developing new industrial complexes, or revitalizing the existing agricultural industry; therefore, very few existing methods can be referred to in this regard. At the time, YCG and experts tried to find content that the elderly could benefit from on their own rather than a grand plan; in particular, they did not collect the opinions of residents after making a decision but discussed solutions during the first stage of planning. Then, through the process of seeking and organizing the residents, as well as negotiating with them, the administrators and experts confirmed that practicable sustainability is possible through the creation of profits centered on residents.

After the central government confirmed support, residents' meetings were held 31 times, residents' capacity building education was conducted 9 times, and administrative and expert support meetings were held 34 times [21] (p. 25). As a result, they focused on the "muk" production of the grandmothers in their daily lives rather than the typical agriculture as in rural areas. This is a jellied food made from acorns or buckwheat, which residents often produce due to the many acorn trees around the village. It was envisioned that residents could make "muk" together and sell it to other regions to enable economic independence. In addition, grandfathers discussed running a carpentry workshop (which was also considered profitable) by selling household items such as cutting boards and furniture. In particular, the carpentry workshop was planned so that residents could improve their area in the future by not only selling but also repairing the village environment and their homes.

The idea for this non-agricultural business was conceived by residents during a residents' meeting. The administration and experts supported the establishment of a system in which residents could continue to implement it. First, the workforce that could participate in each project was organized into project teams. After deciding on the solution, in consideration of sustainable operation and management, education about similar businesses, economy, and regional activation was conducted for a year and a half.

Table 2 summarizes community participation and content in the preparation and specific planning process of the Guseong Village improvement projects. 
Table 2. Community participation in the improvement planning for Guseong Village.

\begin{tabular}{|c|c|c|c|c|c|c|}
\hline Phase & Period & Main Purpose and Contents & Decision Maker & Community & \multicolumn{2}{|c|}{ Participation } \\
\hline $\begin{array}{l}\text { Preparation: initial } \\
\text { envision }\end{array}$ & Around one year & $\begin{array}{l}\text {-Preparation of application for } \\
\text { financial support } \\
\text {-Status survey and general } \\
\text { direction decision }\end{array}$ & $\begin{array}{l}\text { MOLIT }{ }^{1}, \mathrm{YCG}^{2}, \\
\text { expert }^{3}\end{array}$ & $\begin{array}{l}\text {-Guseong Village } \\
\text { Council: first } \\
\text { organization }\end{array}$ & $\begin{array}{l}\text {-Resident presentation: } \\
\text { once }\end{array}$ & $\begin{array}{l}\text {-Site survey: } 24 \text { times-Residents' } \\
\text { meeting: } 27 \text { times } \\
\text {-Resident interview: } 43 \text { people } \\
\text {-Survey: } 74 \text { people } \\
\text {-Education: } 19 \text { times }\end{array}$ \\
\hline \multirow{2}{*}{$\begin{array}{l}\text { Initiation: concrete } \\
\text { planning }\end{array}$} & Around one year & $\begin{array}{l}\text {-Deriving specific solutions } \\
\text { through participatory } \\
\text { planning }\end{array}$ & $\mathrm{YCG}^{2}$, expert ${ }^{3}$ & $\begin{array}{l}\text {-Resident Promotion } \\
\text { Committee: reorganized } \\
\text {-Activist: selected } \\
\text {-Project Promotion } \\
\text { Council: reorganization }\end{array}$ & -Resident workshop: once & \multirow{2}{*}{$\begin{array}{l}\text {-Residents' meeting: } 31 \text { times } \\
\text {-Education: nine times }\end{array}$} \\
\hline & $\begin{array}{l}\text { Around one year } \\
\text { and a half }\end{array}$ & $\begin{array}{l}\text {-Construction of public } \\
\text { community facilities, } \\
\text { preparation for operation and } \\
\text { management by residents }\end{array}$ & $\mathrm{YCG}^{2}$, expert $^{3}$ & $\begin{array}{l}\text {-Project Teams: } \\
\text { reorganization }\end{array}$ & $\begin{array}{l}\text {-Basic and in-depth } \\
\text { education on social } \\
\text { economy (nine months) } \\
\text {-Preliminary project: two } \\
\text { times (seven months) }\end{array}$ & \\
\hline
\end{tabular}

${ }^{1}$ Ministry of Land, Infrastructure and Transport; ${ }^{2}$ Yeongju City Government; ${ }^{3}$ Guseong Village Coordinator Team. 


\subsection{Construction of Public Facility and Operation of Community}

In accordance with the plan for a new production system for the sustainability of life, centered on the local elderly, the administration and experts in this regard decided on the program of public community facilities. Muk and woodworking were linked to facilities called Grandma Muk Factory and Grandpa Wood Factory, respectively, and each name was given by residents of the project teams. The administration ensured that these public community facilities became common hub spaces to maintain residents' sustainable living. Accordingly, YCG purchased the neglected land in the area and constructed two facilities with a total floor area of 148.8 and $269 \mathrm{~m}^{2}$, respectively. Discussions were held with the residents about necessary matters related to the facility, but they did not participate in the design of the building, the selection of architects, or the construction itself. At that time, residents of each project team prepared for business through educational programs, such as lectures and field visits supported by the administration and experts. They learned practical duties as operators through basic and in-depth education on the social economy. Particularly, while conducting preliminary projects, the full project was started on a pilot basis by operating promotional booths at local festivals.

After the facilities were constructed, the project groups established a "Social Cooperative" to initiate operation and management by residents; while the administration and experts helped the process, the residents directly contributed around USD 455 each to form the organization. The total number of residents participating was approximately 21 , with an average age of 78 years [25]. With the opening ceremony, sales began in earnest, and the residents' operation and management of the facility continued (Figure 4). Local residents help and work together; in particular, the Grandma Muk Factory directly produces and sells muk and tofu, and the maximum production per day is only around 100 [26]. Various types of vegetables are grown and sold at the "Grandma Garden", next to the facility, with annual sales of approximately USD 82,000. This is, in fact, a slow food, which actually makes a small profit compared to other large factories. Likewise, the Grandpa Wood Factory does not mass-produce products. However, local residents did not want to create enormous wealth through these new solutions. It is significant that residents have radically changed their way of living through their own independent and proactive economic life-rather than passively relying on welfare-in a region where agricultural recovery or the new tourism industry could not be expected at all.

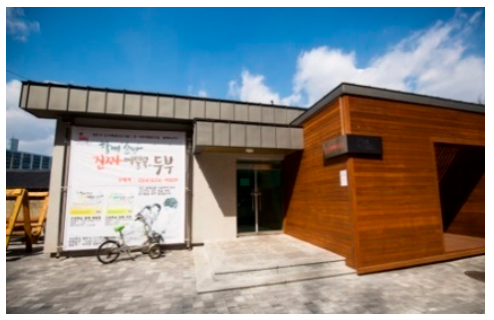

(a)

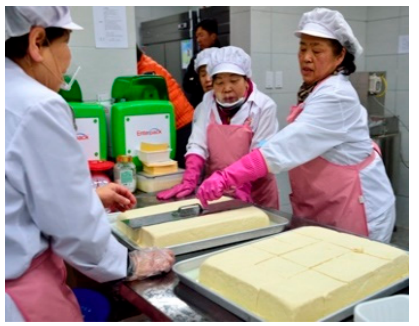

(b)

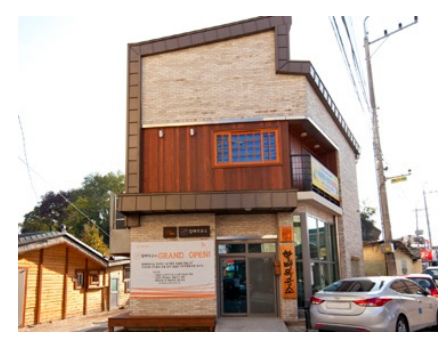

(c)

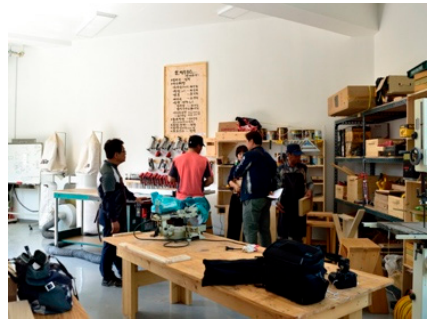

(d)

Figure 4. Public community facilities and operation by residents: (a,b) Grandma Muk Factory and residents; (c,d) Grandpa Wood Factory and residents (Source: YCG).

The administration and experts established and linked an online system and courier system through which residents could sell nationwide. Public facilities are owned by the government, but contracts are signed by consignment to the local community [27]. The government continues to provide support by consulting and monitoring residents' business operations.

Table 3 summarizes the programs and operations of these two facilities. 
Table 3. Program and operation of public community facilities in Guseong Village.

\begin{tabular}{|c|c|c|c|c|}
\hline Facilities & Location and Scale & Program & Operator and Roles & Owner and Roles \\
\hline $\begin{array}{c}\text { Grandma Muk } \\
\text { Factory }\end{array}$ & $\begin{array}{l}\text {-Location: } 296-7, \\
\text { Yeongju-dong } \\
\text {-Scale: one storey above } \\
\text { ground, total floor area } \\
148.8 \mathrm{~m}^{2}\end{array}$ & $\begin{array}{l}\text {-Muk and tofu making } \\
\text {-Garden operation } \\
\text {-Online and offline sales }\end{array}$ & $\begin{array}{l}\text {-Guseong Village } \\
\text { Community: Grandma Muk } \\
\text { Factory Social Cooperative } \\
\text {-Production, sales, facility } \\
\text { operation and management }\end{array}$ & \multirow{2}{*}{$\begin{array}{l}\text {-Administration: } \mathrm{YCG}^{1} \\
\text {-Consignment } \\
\text { agreement for urban } \\
\text { facilities, consulting } \\
\text { and monitoring for } \\
\text { business operation }\end{array}$} \\
\hline $\begin{array}{c}\text { Grandpa Wood } \\
\text { Factory }\end{array}$ & $\begin{array}{l}\text {-Location: } 290-13, \\
\text { Yeongju-dong } \\
\text {-Scale: two stories } \\
\text { above ground, total } \\
\text { floor area } 260 \mathrm{~m}^{2}\end{array}$ & $\begin{array}{l}\text {-Production of } \\
\text { household goods such } \\
\text { as furniture } \\
\text {-Offline sales }\end{array}$ & $\begin{array}{l}\text {-Guseong Village } \\
\text { Community: Grandpa Wood } \\
\text { Factory Social Cooperative } \\
\text {-Production, sales, facility } \\
\text { operation and management }\end{array}$ & \\
\hline
\end{tabular}

${ }^{1}$ Yeongju City Government.

\section{Discussion}

In this case, no communities had previously made public demands or campaigned to contrast the serious decline of this rural area, and the elderly population rate was high. In this situation, the main characteristics of resident-centered sustainable results are as follows:

- The government established a cooperative structure by continuously supporting and encouraging participation in the community with a long-term perspective;

- Experts who played a role between the administration and the residents remained the same since the initial investigation stage and thus envisioned a concrete plan and implementation;

- Participating communities were not fixed and were flexibly reorganized as the project progressed;

- A new non-agricultural business suited to the local situation was planned according to the opinions of the residents, leading to an independent operation;

- Public facilities were built using idle land in the area, creating a public space that became a base for residents.

In the case of Korea, where participatory public planning began in earnest after the 2000s, the administration must often start by seeking the community and inducing participation when promoting projects to contrast the decline. As explained in Section 1, promotion by the private sector, including the community, is infrequent, and a major characteristic of Korea is that many projects to improve the urban and architectural environment are carried out under the leadership of the administration. Therefore, in such a situation, cooperative planning with residents does not necessarily mean that the community becomes the decision maker for all implementations. In other words, the active and voluntary participation of the residents do not mean that the administration only provides financial support and then gives residents freedom to do anything. In a situation like Korea's, public objectivity may be replaced by a small number of private interests [28] (pp. 74-83), and the ideal approach to community participation often overlooks this aspect [29] (p. 350). Administration should consider ensuring that the community is aware of the appropriate roles, rights, and responsibilities so that they can engage in projects within an equal structure of cooperation. Support such as presentations, workshops, and education should be provided continuously. This can be understood as a partnership between the public and private sectors, which provides resources to both parties through mutual agreement [30].

In this case, the administration first became aware of the decline issue in the region and began to pursue projects for improvement, setting out a rough scope and direction for the business; however, this did not mean that they decided on all the specific solutions and made the experts and the community follow them. First, experts were involved from the outset in order to find residents to discuss with them; the expert group comprised people who would be involved in business in the long term rather than simply those 
executing contracts. They played a practical role in helping residents understand the project, drawing their opinions, and shaping the plans that had been discussed. In public urban and architectural projects, it is important to promote and implement this form of integrated perspective, as the initial design has a high correlation with the process and results. However, in long-term public works, it is effective to give a role to the expert group so that it can continue to oversee projects because the public officials in charge of this are likely to change according to the political situation [31] (pp. 11-14). In Korea, the qualification standards and scope of work for private experts were stipulated in the Basic Building Act, and in 2021, an integrated management system is planned to be specified through the enactment of a special law.

Initially, most of the elderly residents did not trust and cooperate with the administration and experts. However, they actively participated in the discovery of businesses for local sustainability through continuous discussions and education. Moreover, the content, methods, and names for non-agricultural businesses were not all recommended and presented by the administration and experts; they were conceived by the residents, which was made possible through consultations spanning around a year.

In particular, the administration and experts formed a community group in the process of seeking participants in the early stages, but this did not fix the community. Participatory public planning under the condition that community formation by administration is essential is in a completely different situation from existing discussions on the type of participation that presupposes sufficient participants [32-34]; therefore, it is not appropriate to classify communities according to their level and scope. Rather, flexible access to the community is an important factor in sustainability [16]. Instead of simply focusing on creating an organization that is easy to cooperate with the administration and experts, they consulted each other by continuing to seek out residents who could participate and to flexibly adjust the organization according to progress.

Throughout the process, the communities were organized or reorganized into a total of five groups. The Guseong Village Council, which was initially organized with people interested in local public improvement projects, was reorganized into the Resident Promotion Committee, composed of more diverse residents, and the regeneration project was then implemented in earnest. In addition, an activist was elected from among the residents who, alongside others, formed a resident council related to the entire regeneration project in the center. After the program was integrated into a muk factory and a carpentry workshop, the related residents were reorganized into project teams in the process of creating related facilities and preparing for residents' operations. Through this process, not only residents who participated in the early stage but also those who were unable to get an opportunity to participate were involved. Furthermore, as the organization was gradually composed of those who were suitable for public projects, a much smoother structure of cooperation could be formed.

Administration and experts assisted residents in shaping feasible rough initiatives and creating a distribution system. In particular, one of the aspects that they considered important for sustainability was the creation of public facilities for the community: even after the end of the regeneration project, residents would continue their activities based on the existing public space. In particular, in the capital city of Seoul, sustainability through residents' operation of public community facilities has been verified [35].

In addition, for around a year and a half after planning and decision, residents spent enough time training to operate and manage operations independently in the future. Administration and experts supported business-related education and gave residents the opportunity to conduct preliminary projects in the area. As the owner of public resident facilities, the YCG contracted with them to entrust the operation and management of residents. In particular, considering the elderly, YCG provides consultations on document management and computer work by continuously monitoring residents' businesses. In addition, since there is a possibility that the person in charge will change after the ad- 
ministration has completed the project, YCG's Regeneration Support Center is constantly cooperating with the community because it plays a central role.

Table 4 shows that the major roles of each subject were supplemented based on the main characteristics identified in this study in order to overcome the existing discussions that generalize with a fairly rough approach. This represents the flow of a process that focuses on cooperation in the planning stage under the initial condition that community search and participation induction must be made through administration.

Table 4. Major roles of administration, expert, and community in the cooperative planning process (Source: YCG; reproduced by authors).

\begin{tabular}{|c|c|c|c|}
\hline Procedure & \multicolumn{2}{|c|}{ Administration, Expert } & Community \\
\hline \multirow{8}{*}{ Preparation } & \multirow{2}{*}{\begin{tabular}{l}
\multicolumn{1}{c}{ Internal Organization } \\
-Establish an administrative \\
manpower system for project \\
management, coordination, and \\
management support
\end{tabular}} & \multicolumn{2}{|c|}{ Seeking and Research } \\
\hline & & $\begin{array}{l}\text {-Basic research on the site and } \\
\text { local groups, sharing information } \\
\text { on project promotion with } \\
\text { residents }\end{array}$ & $\begin{array}{l}\text {-Deliver willingness and } \\
\text { opinions on participatory } \\
\text { planning }\end{array}$ \\
\hline & Expert Selection & \multicolumn{2}{|c|}{ First Community Organization } \\
\hline & $\begin{array}{l}\text {-General manager and coordinator } \\
\text { for each field for implementation } \\
\text { and advice }\end{array}$ & $\begin{array}{l}\text {-Residents' meetings, education } \\
\text { for residents }\end{array}$ & $\begin{array}{l}\text {-Voluntary organization or } \\
\text { active cooperation }\end{array}$ \\
\hline & Installation of the Support Center & \multicolumn{2}{|c|}{ Resident Presentation and Opinion Collection } \\
\hline & $\begin{array}{l}\text {-Intermediate support role between } \\
\text { administration and residents }\end{array}$ & $\begin{array}{l}\text {-Share information, interviews, } \\
\text { and surveys }\end{array}$ & $\begin{array}{l}\text {-Discuss opinions on the } \\
\text { project }\end{array}$ \\
\hline & Promotion Committee Organization & \multicolumn{2}{|c|}{ Community Reorganization and Resident Leader Election } \\
\hline & $\begin{array}{l}\text {-Cooperation framework for } \\
\text { administration, expert, community } \\
\text { (including local interested parties) }\end{array}$ & $\begin{array}{l}\text {-Continuous search of various } \\
\text { residents and flexible adjustment } \\
\text { of communities }\end{array}$ & $\begin{array}{l}\text {-Close cooperation with } \\
\text { administration and expert }\end{array}$ \\
\hline \multirow{6}{*}{ Planning } & \multicolumn{3}{|c|}{ Investigation } \\
\hline & \multicolumn{2}{|c|}{$\begin{array}{l}\text {-Identify the key issues of decline and set goals through cooperation with } \\
\text { the community }\end{array}$} & $\begin{array}{l}\text {-Provide opinions on } \\
\text { regional issues and } \\
\text { directions }\end{array}$ \\
\hline & \multicolumn{3}{|c|}{ Planning a Specific Solution } \\
\hline & \multicolumn{2}{|c|}{-Deriving specific solutions with the community } & $\begin{array}{l}\text {-Provide needs and viable } \\
\text { alternatives }\end{array}$ \\
\hline & \multicolumn{3}{|c|}{ Decision and Plan for Action } \\
\hline & $\begin{array}{l}\text {-Review the feasibility and establish } \\
\text { detailed implementation plans for the } \\
\text { final plan }\end{array}$ & $\begin{array}{l}\text {-Decision on final action plan } \\
\text { through consultation with the } \\
\text { community about the review } \\
\text { result }\end{array}$ & $\begin{array}{l}\text {-Review and determine the } \\
\text { possibility of participation } \\
\text { of the final action plan }\end{array}$ \\
\hline \multirow{4}{*}{ Execution } & Action & \multicolumn{2}{|c|}{$\begin{array}{c}\text { Community Reorganization into Project Team, Education, and } \\
\text { PreliminaryWork }\end{array}$} \\
\hline & $\begin{array}{l}\text {-Overall execution based on the } \\
\text { conceived plan }\end{array}$ & $\begin{array}{l}\text {-Support for education and } \\
\text { preliminary projects and election } \\
\text { of leaders related to future } \\
\text { programs }\end{array}$ & $\begin{array}{l}\text {-Participation with } \\
\text { continuous implementation } \\
\text { in mind }\end{array}$ \\
\hline & \multicolumn{2}{|c|}{ Support } & Fulfill \\
\hline & \multicolumn{2}{|c|}{$\begin{array}{l}\text {-Consulting and monitoring for the sustainability of communities and } \\
\text { businesses }\end{array}$} & $\begin{array}{l}\text {-Operation and } \\
\text { management }\end{array}$ \\
\hline
\end{tabular}




\section{Conclusions}

This study explains sustainability through participatory regeneration projects and resident-led, non-agricultural business development in rural areas that have declined due to aging and economic downturns in Korea. In particular, it shows how the administration promotes the project by prioritizing the problem and induces the participation of residents and cooperates with them in the condition of a community composed mostly of elderly people.

Administration and experts have sought and encouraged residents from a long-term perspective and reorganized the community to be flexible rather than static. With sustainability in mind, they recognized the situation in areas where it was impossible to restore existing agriculture or develop new industrial and residential complexes. Accordingly, major initiatives and decisions were devised by the residents so that they could become independent and live a sustainable life. After several training programs and preliminary projects, they became practical operators and managers of local businesses after the regeneration project was completed.

Under circumstances such as this case, cooperative planning with residents does not simply allow the administration and experts to step back and the community to make decisions; ongoing support should be provided until the community becomes voluntary and consultative. In addition, after the project is completed, a considerable period of detailed administrative support is inevitable for the community to operate the facilities and for economic sustainability.

This study, which confirmed key practical characteristics through examples and complemented the major roles of each subject in detail, will prove valuable when discussions and implementations of sustainability through participatory planning and non-agricultural solutions for the declining rural area in Korea are in full swing. This provides data for future discussions and implementation not only in Korea but also under similar conditions in other regions. As in this study, the continuous tracking of cases is necessary.

Author Contributions: Conceptualization, S.G.B. and H.-A.K.; methodology, S.G.B.; software, S.G.B.; validation, S.G.B. and H.-A.K.; formal analysis, S.G.B.; investigation, S.G.B.; resources, S.G.B.; data curation, S.G.B.; writing-original draft preparation, S.G.B.; writing—review and editing, S.G.B.; visualization, S.G.B.; supervision, S.G.B. and H.-A.K.; project administration, S.G.B. and H.-A.K.; funding acquisition, H.-A.K. All authors have read and agreed to the published version of the manuscript.

Funding: This research was supported by the National Research Foundation of Korea (NRF), by a grant funded by the Ministry of Education (NRF-2019R1I1A3A01061072).

Conflicts of Interest: The authors declare no conflict of interest.

\section{References}

1. Yaxin, S.; Yishao, S. Spatio-Temporal Variation Characteristics and Driving Forces of Farmland Shrinkage in Four Metropolises in East Asia. Sustainability 2020, 12, 754. [CrossRef]

2. Han, G. Development and Transformation of Model Korean City. J. Archit. Inst. Korea Plan. Des. 2014, 10, 169-178. Available online: www.dbpia.co.kr/Journal/articleDetail?nodeId=NODE02490607 (accessed on 26 December 2020).

3. KOSIS (Korean Statistical Information Service). 2020. Available online: www.kosis.kr (accessed on 26 December 2020).

4. SBS CNBC. Available online: https:// cnbc.sbs.co.kr/article/10000437476 (accessed on 26 December 2020).

5. Urban Regeneration Information System. Available online: www.city.go.kr/portal/policyInfo/urban/contents01/link.do (accessed on 26 December 2020).

6. Nils-M, W.; Philipp, R. Advancing Revolving Funds for the Sustainable Development of Rural Regions. Sustainability 2020, 12, 8455. [CrossRef]

7. Jennifer, G. Lessons in Rural Persuasion: Village Infill Development in Bavaria, Germany. Sustainability 2020, 12, 8678. [CrossRef]

8. Romina, F.; Serena, C.; Giuseppe, F.; Joao, L. The "Local Town Market Area" in Enna, Sicily: Using the Psychology of Sustainability to Propose Sustainable and Developmental Policies. Sustainability 2019, 11, 486. [CrossRef]

9. Cristian, P.-C.; Margarita, B. Traditional Varieties for Local Markets: A Sustainable Proposal for Agricultural SMEs. Sustainability 2020, 12, 4517. [CrossRef]

10. Tabita, A.; Ramona, C.; Tiberiu, I.; Ioan, B.; Elena, P.; Gabriela, P.; Laura, S. Sustainability of Agritourism Activity. Initiatives and Challenges in Romanian Mountain Rural Regions. Sustainability 2020, 12, 2502. [CrossRef] 
11. Tew, C.; Barbieri, C. The perceived benefits of agritourism: The provider's perspective. Tour. Manag. 2012, 33, 215-224. [CrossRef]

12. MOLIT (Ministry of Land, Infrastructure and Transport). Available online: www.molit.go.kr/english/USR/WPGE0201/m_3685 4/DTL.jsp (accessed on 10 January 2021).

13. Nieves, G.-C.; Luis, A.S.-P. Internships for Higher Education Students to Promote the Local Sustainability of Rural Places. Sustainability 2020, 12, 4926. [CrossRef]

14. Lee, T. Plan to Revitalize Urban Regeneration Projects with Private Participation; Construction \& Economy Research Institute of Korea: Seoul, Korea, 2020; pp. 3-6. Available online: www.e-ia.co.kr/cg/vol248/248_news.pdf (accessed on 10 January 2021).

15. Baek, S.G. The Characteristics of Community Participation in the Production of Public Places in Korea. Ph.D. Thesis, Seoul National University, Seoul, Korea, 2020. Available online: s-space.snu.ac.kr/handle/10371/167572 (accessed on 10 January 2021).

16. Baek, S.G.; Kwon, H.-A. Participatory Planning through Flexible Approach: Public Community Facilities in Seoul's Urban Regeneration Project. Sustainability 2020, 12, 10435. [CrossRef]

17. Yeongju City Government. Available online: www.yeongju.go.kr/open_content/main/page.do?mnu_uid=3738\& (accessed on 10 January 2021).

18. Baek, S.G.; Chung, H.; Kim, K. A Study on the Facility Types and Urban Spatial Changes in Suwon in Modern Age: Focusing on the Facilities Distribution in connection with Agriculture Facility and Railway in Suwon during the Japanese Colonial Era. J. Archit. Inst. Korea Plan. Des. 2014, 32, 77-85. Available online: www.koreascience.or.kr/article/JAKO201632747975151.page (accessed on 10 January 2021).

19. Yeongju City Government. 2009 Final Report of National Land Environment Architecture Design Demonstration Project; Ministry of Land, Infrastructure and Transport: Sejong, Korea, 2013.

20. Cha, J.; Cho, J.; Park, S. Creating Good Public Architecture: Focusing on Yeongju City's Attempts; Architecture \& Urban Research Institute: Sejong, Korea, 2014.

21. Ban, Y. The Story of Reversal in front of the Station, Yeongju. In Architecture and Urban Space; Architecture \& Urban Research Institute: Sejong, Korea, 2016; Volume 23, pp. 23-31.

22. Kim, D. Characteristics of Plans and Projects in Areas leading Urban Regeneration; Architecture \& Urban Research Institute: Sejong, Korea, 2014.

23. Park, J. Creating Happiness for Grandpa and Grandma in Guseong Village. In Village Community Best Practices Book: Our Village Story; Korea Local Promotion Foundation: Seoul, Korea, 2017; pp. 26-33.

24. KHBA (Korea Housing Builders Association). Available online: www.jutek.kr/user/selectBbsColumn.do?BBS_NUM=1170 \&COD03_CODE=c0318 (accessed on 10 January 2021).

25. Guseong Village. Available online: gsvillage.kr/bbs/content.php?co_id=gsvillage0301 (accessed on 10 January 2021).

26. Grandma Muk Factory. Available online: halmaemuk.kr/bbs/content.php?co_id=halmaemuk0101 (accessed on 10 January 2021).

27. Yeongju Urban Regeneration Support Center. Available online: www.yjrc.kr/theme/city/index/sa_01.php (accessed on 26 December 2020).

28. Lee, S.; Kim, H. Citizen Participation Theory; Pakyoungsa: Seoul, Korea, 2018; pp. 74-83.

29. Duffy, K.; Hutchinson, J. Urban Policy and the turn to Community. Town Plan. Rev. 1997, 68, 347-362. [CrossRef]

30. Woo, T. A Study on Urban Regeneration Direction and Legal System Improvement of Resident Participation. Korean Soc. Judic. Adm. 2018, 59, 40-58. Available online: http:/ / www.dbpia.co.kr/journal/articleDetail?nodeId=NODE07552604 (accessed on 10 January 2021).

31. Sim, K.; Lee, H.; Kim, M. Improvement of City System in South Korea; Architecture \& Urban Research Institute: Sejong, Korea, 2020.

32. Arnstein, S. A Ladder of Citizen Participation. J. Am. Inst. Plan. 1969, 35, 216-224. Available online: www.tandfonline.com/doi/ abs/10.1080/01944366908977225 (accessed on 10 January 2021).

33. Milbrath, L. Political Participation. In The Handbook of Political Behavior; Samuel, L., Ed.; Springer: Boston, MA, USA, 1981; Volume 4, pp. 197-240. Available online: link.springer.com/chapter/10.1007/978-1-4684-3878-9_4 (accessed on 10 January 2021).

34. Connor, M. A New Ladder of Citizen Participation. Natl. Civ. Rev. 1988, 77, 249-257. Available online: geog.sdsu.edu/People/ Pages/jankowski/public_html/web780/Connor_1988.pdf (accessed on 26 October 2020).

35. Seoul Urban Regeneration. Available online: uri.seoul.go.kr/eng/achv/ecnmDvlpRgnrList.do?prmtn_prfrm_type=03 (accessed on 10 January 2021). 